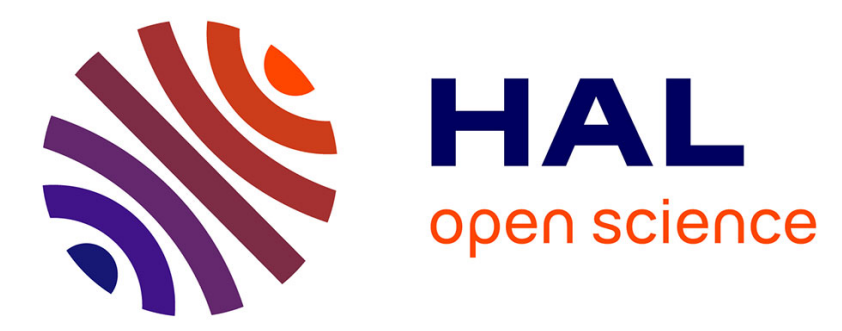

\title{
Stakeholder involvement and the management of animal genetic resources across the world
}

\author{
Grégoire Leroy, R. Baumung, D. Notter, Etienne Verrier, M. Wurzinger, B.
} Scherf

\section{- To cite this version:}

Grégoire Leroy, R. Baumung, D. Notter, Etienne Verrier, M. Wurzinger, et al.. Stakeholder involvement and the management of animal genetic resources across the world. Livestock Science, 2017, 198, pp.120-128. 10.1016/j.livsci.2017.02.018 . hal-01602715

\section{HAL Id: hal-01602715 https://hal.science/hal-01602715}

Submitted on 26 May 2020

HAL is a multi-disciplinary open access archive for the deposit and dissemination of scientific research documents, whether they are published or not. The documents may come from teaching and research institutions in France or abroad, or from public or private research centers.
L'archive ouverte pluridisciplinaire HAL, est destinée au dépôt et à la diffusion de documents scientifiques de niveau recherche, publiés ou non, émanant des établissements d'enseignement et de recherche français ou étrangers, des laboratoires publics ou privés.

\section{()(1)(2)}

Distributed under a Creative Commons Attribution - ShareAlikel 4.0 International 


\title{
Stakeholder involvement and the management of animal genetic resources across the world
}

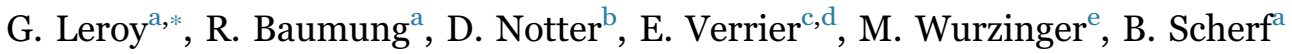 \\ a Food and Agriculture Organization of the United Nations, Animal Production and Health Division, Viale delle Terme de Caracalla, o0153 Rome, Italy \\ b Virginia Polytechnic Institute \& State University, Department of Animal and Poultry Sciences Blacksburg, United States \\ c AgroParisTech, UMR 1313 Génétique Animale et Biologie Intégrative, France \\ d INRA, UMR 1313 Génétique Animale et Biologie Intégrative, Jouy-en-Josas, France \\ e BOKU-University of Natural Resources and Life Sciences, Division of Livestock Sciences, Vienna, Austria
}

\section{A R T I C L E I N F O}

\section{Keywords:}

Livestock

Stakeholder

Breeding

Conservation

Governance

Genetic resources

\begin{abstract}
A B S T R A C T
The sustainability of activities related to animal genetic resources (AnGR) management depends largely on the participation of a range of stakeholders, both public and private. In this study, we investigated factors explaining differences in stakeholder involvement in AnGR management across countries, based on an historical perspective and an analysis of the 128 official country reports provided during preparation of The Second Report on the State of the World's Animal Genetic Resources for Food and Agriculture. Results of principal component analyses indicated that countries differed in the involvement of stakeholders in AnGR management, generally with greater involvement of livestock breeders and their organizations in developed countries. Developing countries tended to be divided into two groups, those with little involvement by stakeholders and those with high involvement by government/research organizations. Depending on the country, the involvement of government/research organizations versus breeders/livestock keepers organizations and commercial companies also differed, which could be linked to some extent to their historical background. The level of involvement of breeders 'associations or cooperatives was positively correlated $(r=0.68)$ to the general extent of AnGR activities within the country. Our results underline the importance of involving breeders and livestock keepers in the development of management activities, while public support is required as well, especially in the early stages of capacity development. In developing countries, development policies relative to AnGR management should therefore seek to promote coordination among livestock keepers through creation and empowerment of cooperatives, associations or community-based approaches.
\end{abstract}

\section{Introduction}

Animal Genetic Resources (AnGR) have a critical role in the provision of food and other services such as workforce, fiber, fertilizer, landscape management, and capital. Over the last several decades, the productivity of livestock has improved in developed countries, mainly through the application of more efficient breeding programs (Havenstein et al., 2003). In developing countries, the demand for animal products is currently increasing and is expected to increase over the next few decades. Attempts to meet this growing demand have often focused the importation of exotic breeds, largely because of the low productivity of local breeds and challenges in the implementation of effective breeding schemes to quickly improve productivity (Wurzinger et al., 2011; Leroy et al., 2016a). This situation is a threat to local genetic resources. Country-level data collected for The Second
Report on the State of the World's Animal Genetic Resources for Food and Agriculture (SoW2) were used to assess the management, status, and trends in AnGR and provided the basis for an appraisal of the challenges that animal genetic resources are currently facing (FAO, 2015). One main finding was that the institutional framework and capacity to properly manage AnGR require strengthening, to improve the characterization, selection and conservation of local livestock breeds. This finding is in agreement with literature (Wurzinger et al., 2011; Zonabend et al., 2013). The situation differs among countries. Statistical analyses (Leroy et al., 2016b), based on the 128 country reports coordinated by government-nominated National Coordinators for the SoW2, specifically showed a large difference in the extent of AnGR activities between OECD and BRICS (Brazil, Russia, India, China and South Africa) countries compared to less developed countries (for example: characterization, breeding programs, conservation and use of

\footnotetext{
* Corresponding author.

E-mail address: Gregoire.Leroy@fao.org (G. Leroy).
} 
reproductive biotechnologies).

Several studies have emphasized that the sustainability of AnGR management activities depends on, among other things, the participation of a diversity of stakeholders (Rewe et al., 2009; Lauvie et al., 2011; Wurzinger et al., 2011; Zonabend et al., 2013; Mueller et al., 2015). Those stakeholders include livestock keepers (generally associated with small-scale livestock production) and breeders (a term generally applied to farmers involved in more sophisticated breeding programs), either individually or organized in associations or cooperatives. In developing countries, community-based organizations are also becoming recognized as important partners for implementation of sustainable breeding programs (Wurzinger et al., 2011). Commercial companies, either country-based or international, are also potential major stakeholders in the breeding process. Research organizations, either public or private, and public services (government, veterinary and extension services) may also have an important role to play. Finally, civil society organizations and, to a lesser extent, international donors may also be involved in AnGR activities, mostly in developing countries. The question of stakeholders participation is important because animal genetic resources, and especially ruminants, have commonly been managed as a common good (Labatut et al., 2013) involving private and public interests. Stakeholder involvement includes participation in policy-level activities (implementation, establish of data recording programs, provision of services, decision making, etc.) as well as specific animal-level activities (animal identification, artificial insemination, genetic evaluation etc.) Stakeholder involvement may, however, differ among species and countries, or even within countries, depending on the array of engaged stakeholders and their relationships to animal production (Faco et al., 2011).

The SoW2 country reports included responses to several questions related to stakeholder participation, providing an opportunity to understand the degree of involvement of the various actors across the world and in relation to a range of AnGR activities. The aim of this study was therefore to analyze factors that explain differences in stakeholder involvement in activities related to AnGR management and to investigate the link between stakeholder involvement and the overall extent of AnGR management activities. A historical perspective on stakeholder involvement is provided based on a brief literature review. We then use the results from the SoW2 country reports to investigate current differences in AnGR management across activities, species and countries, with particular emphasis on the situation in developing countries. Finally, the potential impact of new technologies on the various actors is discussed.

\section{Material and methods}

The first step in the study was a brief literature review of the historical involvement of various actors in AnGR management in different countries. The aim of this first section is to assess how stakeholder involvement has evolved through time and been impacted by specific historical circumstances.

Next, in order to illustrate differences in stakeholders' involvement in AnGR management across the world, an analysis was conducted of the 128 Country reports provided to FAO during the preparation of SoW2. These country reports are available at http://www.fao.org/3/a$\mathrm{i} 4787 \mathrm{e} / \mathrm{i} 4787 \mathrm{e} 01 . \mathrm{htm}$. A questionnaire was provided to the authors of the country reports and included explanations and definitions of terms to ensure that responses were as consistent as possible. Three questions from the SoW2 country reports were selected for this analysis, dealing with (i) the extent to which livestock keepers are organized for the purpose of animal breeding (including breeders), (ii) the level of stakeholder involvement in the various elements of breeding programs, and (iii) methods used for in situ conservation programs by the private and public sector.

Depending on the question, different stakeholders were considered in the reporting format (see Table 1). Potential stakeholders included
Government (Gov), Breeders/livestock keepers (BreLK), Breeders associations or cooperatives (BreAC), National commercial companies (NComC), External commercial companies (EComC), NonGovernmental organizations (NGO), Research organizations (ResO), Public sector (PubS) (referring here mainly to governmental services and public research institutes), and the Private sector (PrivS) (referring here mainly to associations and NGOs). The study was limited to the "big five" species: cattle, sheep, goats, pigs and chickens, and the questionnaire considered dairy, beef, and multipurpose cattle separately.

Responses to the questions were converted into numerical values (either no $=0$ and yes $=1$ or none $=0$, low $=1$, medium $=2$, and high $=3$ ), and missing data were imputed using an iterative Principal Component Analysis (PCA) (Josse and Husson, 2012). Variables were then scaled to unit variance, and PCA was applied to investigate factors that discriminate among answers from different countries, considering effects of stakeholders, species or other items. The PCA was conducted independently for each question as if answers to the three questions were analysed together, the questions themselves appeared as the first discriminating factor (data not shown). Resulting synthetic uncorrelated variables were then ranked according to the amount of the variance (inertia) in the data set that was explained. For the PCA, each country was considered as an observation and the country scores for each of the different questions (Table 1) were the variables that were analysed.

To test the relationship between stakeholders' involvement and the implementation of AnGR activities, results for Question 2 (stakeholders involvement in the various elements of breeding programs) from the current study were correlated with a synthetic variable corresponding to the first axis of a PCA of 229 variables related to questions from the SoW2 country reports dealing with characterization, use and conservation of animal genetic resources (Leroy et al., 2016b). This variable explained $34.7 \%$ of the inertia of the former data set and was considered to represent the general extent of AnGR activities implemented within the countries. Correlations between answers relative to stakeholder involvement in the various elements of breeding programs in the current study and this synthetic variable were computed and averaged for each stakeholder class (i.e., across 7 species related groups x 5 activities 35 correlations coefficients per stakeholder class).

\section{Results}

\subsection{Participation of stakeholders in breeding activities: historical perspective}

Artificial selection of breeding animals is generally considered to have occurred since the beginning of domestication process. However, breeding activities in a modern sense, i.e. the systematic selection of relatively large number of animals over several generations to improve specific traits, was initiated in Europe in the late XVIII ${ }^{\text {th }}$ and early XIX $^{\text {th }}$ centuries (see, for instance, Wood and Orel, 2001). Following pioneering work by breeders such as Bakewell and the Colling brothers, the first herd-books were created under the leadership of charismatic farmers and with the support of the first agricultural societies and private initiatives, such as agricultural shows (Bougler and Delage, 1999). Public institutions, i.e. agricultural and veterinary services were involved from the beginning of the planned breeding. In Europe, active state intervention in agriculture arose already during the XIXth century (Friedmann and McMichael, 1989). For instance, at the beginning on XIXth century, the use of Merino rams was promoted by the Napoleonian administration, for military purposes, to improve the French breeds' wool quality (Wood and Orel, 2001).

A strong development of animal breeding activities and organizations occurred in Europe and North America during the $\mathrm{XX}^{\text {th }}$ century. In particular, performance recording on farm was developed during the first half of the century and artificial insemination (AI) in some species 


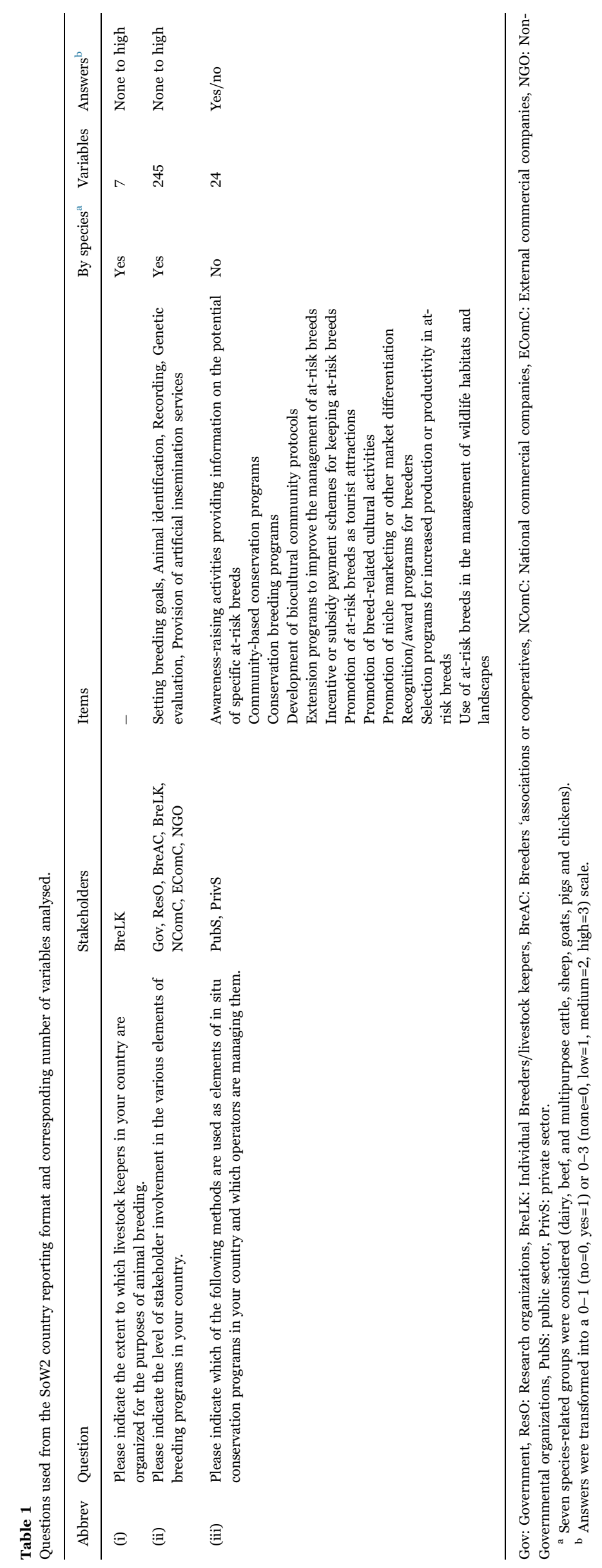




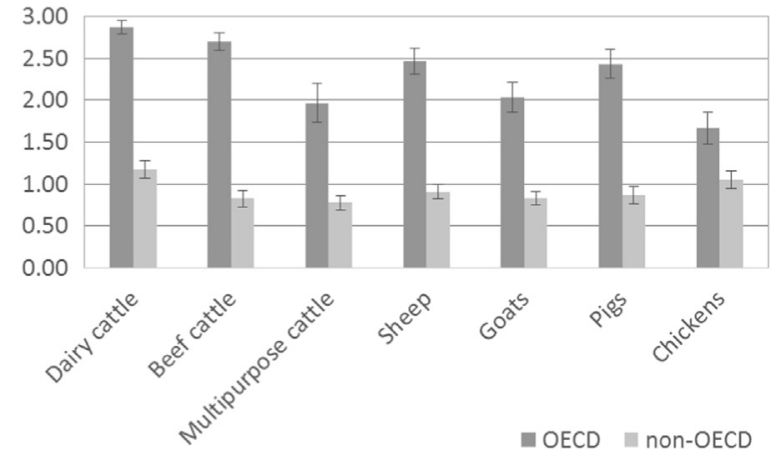

Fig. 1. Extent of organization of livestock keepers for the purpose of animal breeding, with reported scores converted into numerical values (none $=0$; low $=1$; medium $=2$; high $=3$ ).

was developed and utilized during the second half. These developments mainly resulted from farmers initiatives through breeders associations or AI cooperatives. Beginning in the 1950s, the concepts and methods of quantitative and population genetics were applied in breeding programs by a strong collaboration between breeding organizations and higher education institutions or research institutes. The structure of the breeding organizations depended on the species: mostly private companies in poultry, breeders associations or cooperatives in ruminants, and both in pigs. In the USA, in the XIX and XXth centuries, different pieces of legislation (the Morrell Act, the Hatch Act, the Smith-Lever Act, and the G.I. Bill), provided for the establishment of universities in the different states to offer training in agriculture and development of research through the establishment of experiment stations and strengthening of education and training, thereby providing the human capacity for rapid development of American agriculture (National Research Council, 1995). In France a law passed (almost unanimously) in 1966 provided, for 40 years, the breeding industry with a legal framework spelling out the respective responsibilities of different organizations (see, for instance, Vissac, 2002).

In Latin American countries, the development of commercial agriculture and the creation of national research institutes began in the second half of the XXth century, facilitating the coordination and implementation of agricultural research (Byerlee and Echeverría, 2002; Stads and Beintema, 2009). These events led to the frequent emergence of private-public partnerships and a relatively high involvement of the private sector compared with other developing regions. In Brazil, initiatives to implement selection programs began in the 1950s with strong partnerships between groups of farmers, research institutes and private companies. The Brazilian government also implemented specific regulations to support the genetic improvement of livestock, such as the Special Certificate of Identification and Production (CEIP), which was implemented in 1989 to favor the use of improved bulls (Ferraz and Eler, 2010; Carvalheiro, 2014).

In African countries like Kenya, Nigeria, and Zimbabwe, colonial development policies emphasized the importation of European dairy cattle breeds for crossbreeding, but with limited success due to the lack of adaptation of exotic livestock (Conelly, 1998, Ogbimi and Oyewale, 2000; Hove, 2015). Divergent interests between the colonial administration and farmers (both European and African) appeared to have impacted the implementation of development policy, with, for instance, the implementation of regulations excluding African producers from the colonial dairy industry (Hove, 2015). In Kenya, according to Conelly (1998), domestic policy largely ignored local livestock keepers and failed to recognize the important role of women as farmers and livestock caregivers. Post-colonial policies were rarely modified to learn from previous mistakes, and often continued indiscriminate importations of exotic animals after independence.

The participation of public stakeholders in breeding and livestock development activities has been tightly linked to the general level of involvement of the state and to policy-makers' vision for development of the livestock sector. Coleman (1998) compared the role of the state in agricultural development in the USA and European countries from World War II to the end of the 1990s. The role of the state was reduced after the 1980s in the USA, whereas the countries of the European Union maintained a balance between market liberalism and protected development for the sake of social cohesion, promoting, among other things, small family farms. However, since 2000, state involvement and support seem to have decreased in most OECD countries, with, for instance, producer support as a percentage of farm income having decreased from 32\% in 2000 to 19\% in 2011 (OECD, 2015). For example, in France, the 2006 agricultural law liberalized regulations affecting the livestock breeding industry (simplification of the procedure for AI companies to obtain an authorisation from national authorities to operate, reduction of state intervention) (Labatut et al., 2013). In North Vietnam, the structure of the dairy sector evolved from a collective model with state farms in the 1980 s to a development model based on family farms, and more recently changed again to a model involving large-scale dairy farms owned by international companies (Duteurtre et al., 2015).

\subsection{PCA of country reports}

\subsubsection{Extent to which livestock keepers are organized for the purposes of animal breeding}

The degree of organization of livestock keepers and breeders for the purpose of animal breeding varied greatly among countries, regions and species. In OECD countries, the majority of countries reported high or average levels of organization for all species and especially for dairy cattle, where 27 out of 30 countries reported high levels of organization (Fig. 1). Reported levels of organization for OECD countries were lowest for chickens, goats, and multipurpose cattle. In contrast, a majority of non-OECD countries reported low levels of organization for all species.

The PCA for Question 1 (Fig. 2) indicated large correlations between answers (62\% on average), with $68.4 \%$ of total inertia explained by the first axis, leading to, as expected, differenciation between OECD and non-OECD countries. The second axis indicates differentiation among species, with the main contrast between pigs and chickens and other species. Many OECD countries reported similar answers: six countries (Austria AUT, Bulgaria BGR, Czech Republic CZE, Germany DEU, Hungary HUN, The Netherlands NLD) reported a high degree of organization of livestock keepers/breeders for all species, and four countries (Cuba CUB, France FRA, Italy ITA, Spain ESP) reported a high extent of organization of livestock keepers/ breeders for all species with the exception of chicken (low involvement). As an example of a non-OECD country, Algeria (DZA) reported an average extent of organization of livestock keepers in dairy cattle, sheep and goats, low extent for multipurpose cattle, and no organization for beef cattle, chickens and pigs, which, in the latter case, could be related to the absence of production.

\subsubsection{Level of stakeholder involvement in the various elements of breeding programs \\ As shown in Table 1, this question was by far the most complex,} including seven different stakeholders, seven species categories, and five breeding program elements (Setting breeding goals, Animal identification, Recording, Genetic evaluation, and Provision of artificial insemination services).

Fig. 3 shows differences in involvement for the different stakeholders and program elements, with governments more involved in animal identification and less involved in the provision of $\mathrm{AI}$ and genetic evaluation, research organization more involved in setting breeding goals and genetic evaluation, and individual breeders/livestock keepers more involved in setting breeding goals, animal identification and recording. Fig. 4 illustrates clearly that the main difference 


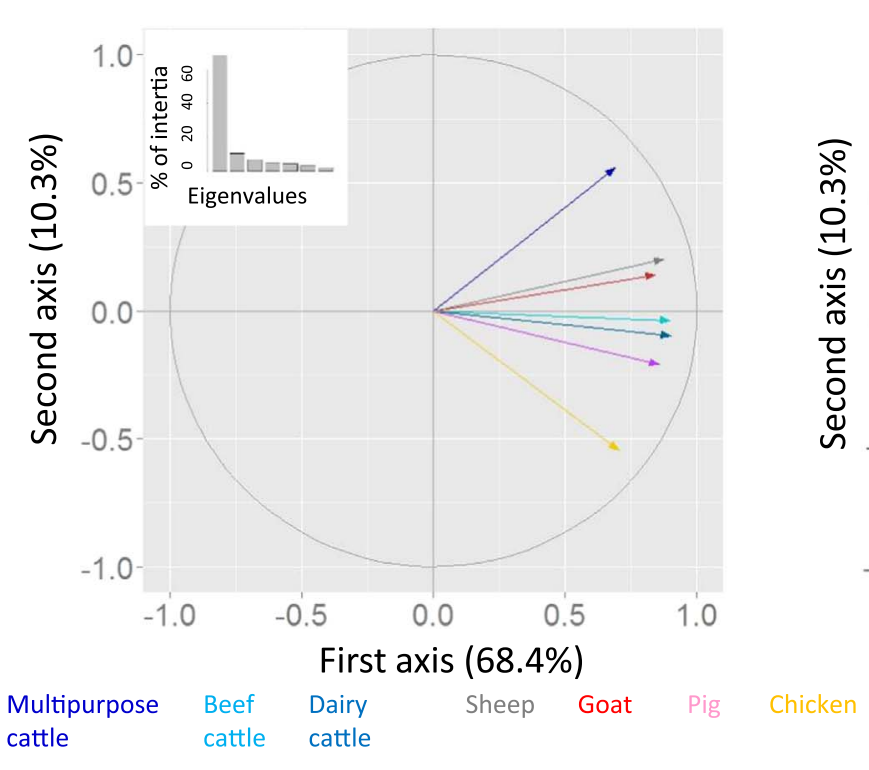

Correlation circle of variables

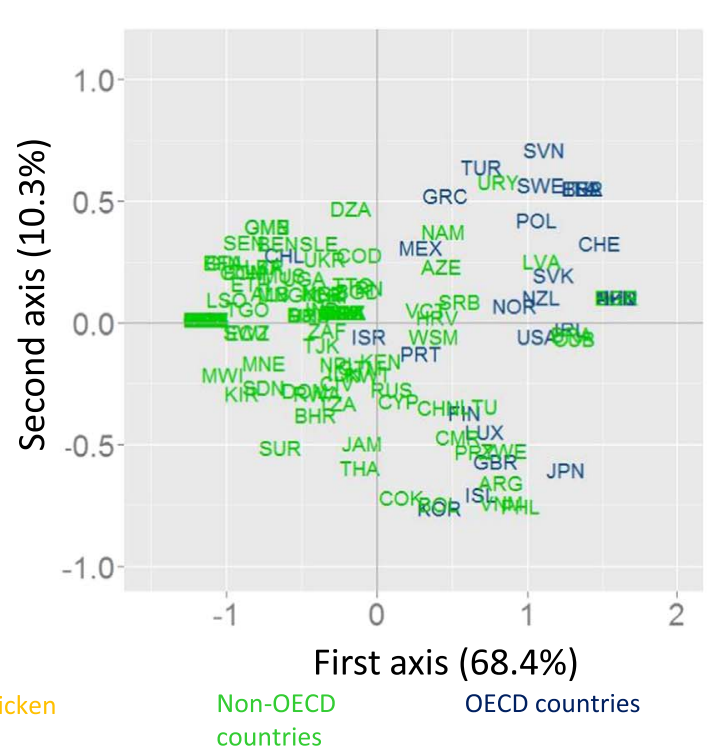

Plotting of countries

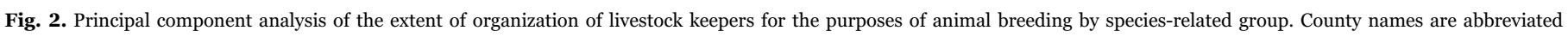
following ISO nomenclature.

between OECD and non-OECD countries relates to the involvement of individual breeders and their associations or cooperatives, which is much more important in OECD countries. In monogastrics, the involvement of national and external commercial companies was relatively important and comparable in importance to other stakeholders, especially in OECD countries. Differences between OECD and non-OECD countries in the involvement of governments, research organizations and NGOs, were small, and the average level of involvement was particularly low for NGOs.

The PCA for Question 2 again yielded positive correlations among the variables ( $28.6 \%$ on average). The first axis of the PCA, accounted for $30.2 \%$ of total inertia and discriminated among groups of countries (Fig. 5). The second axis quantified differences in stakeholders involvement, with Individual Breeders/livestock keepers, breeders' associations or cooperatives, and national and external commercial companies on the one hand, and governments, research organizations and NGOs on the other hand.

Three groups of countries could be identified based on the PCA results (Fig. 5). A first group of non-OECD countries had a general low level of stakeholder involvement. Among countries reporting average or high involvment of stakeholders, differenciation occurred between countries (mostly non-OECD) with high involvment of government and research organization (e.g., Ghana GHA, Vietnam VNM, India IND, China CHN) and countries (both OECD and non-OECD) with greater involvement of individual breeders, breeders' associations or cooperatives and/or commercial companies (e.g., The Netherlands NLD, USA). The particularly high involvement of commercial companies / breeder's association and low involvement of government / research organization reported by the USA appears to be fully in agreement with the observations of Coleman (1998).

The involvement of different stakeholders depended on the species. For instance, South Korea (KOR) reported generally high involvement of government, research organizations, and breeders. The involvement of commercial companies was low except for monogastric species, where their involvement was high. Whereas the involvement of breeders with chickens was reported to be low.

When considering all 128 countries, correlations between stakeholders' involvement in the various elements of breeding programs and the general extent of AnGR activities reported by Leroy et al. (2016b) were positive (average of $\mathrm{r}=37 \%$ ) (Table 2). Correlations were, however, much higher between the extent of AnGR activities and the involvement of breeders 'associations or cooperatives (68\%) and individual breeders/livestock keepers (44\%). The situation once more differed between OECD and non-OECD countries. In non-OECD countries, correlations were positive and high for all stakeholders except for external commercial companies (18\%), ranging between $36 \%$ (NGO) and 59\% (breeders' associations or cooperatives). In OECD countries, correlations were much lower, especially for governments (5\%) and research organizations (9\%); other correlations ranged from $13 \%$ (Individual breeders/livestock keepers) to $41 \%$ (Breeders

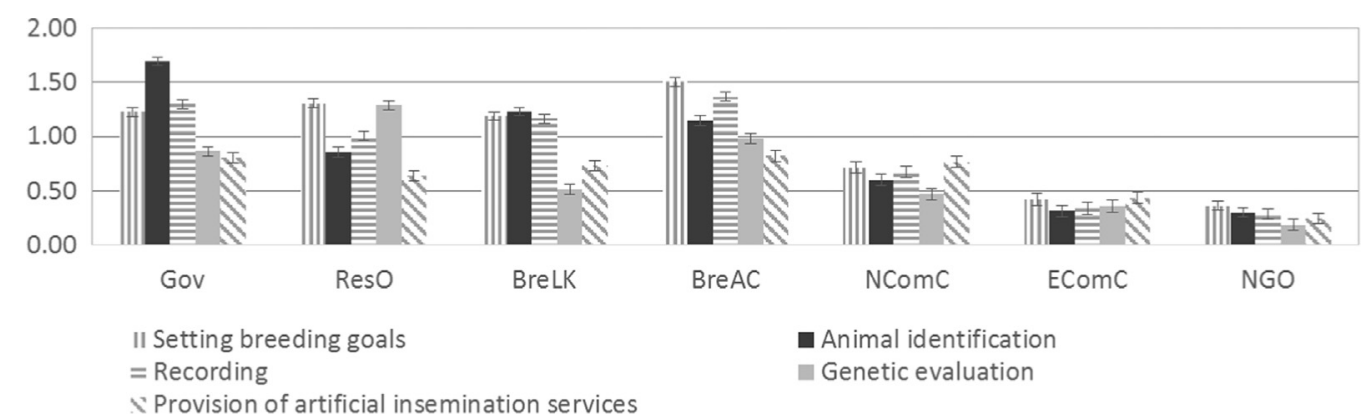

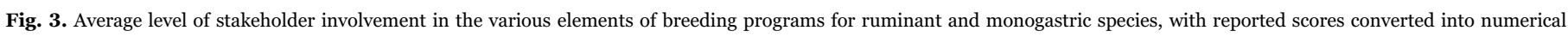

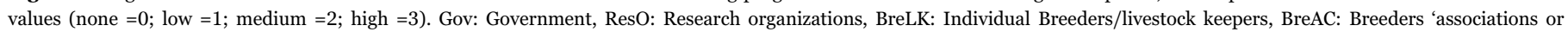
cooperatives, NComC: National commercial companies, EComC: External commercial companies, NGO: Non-Governmental organizations. 


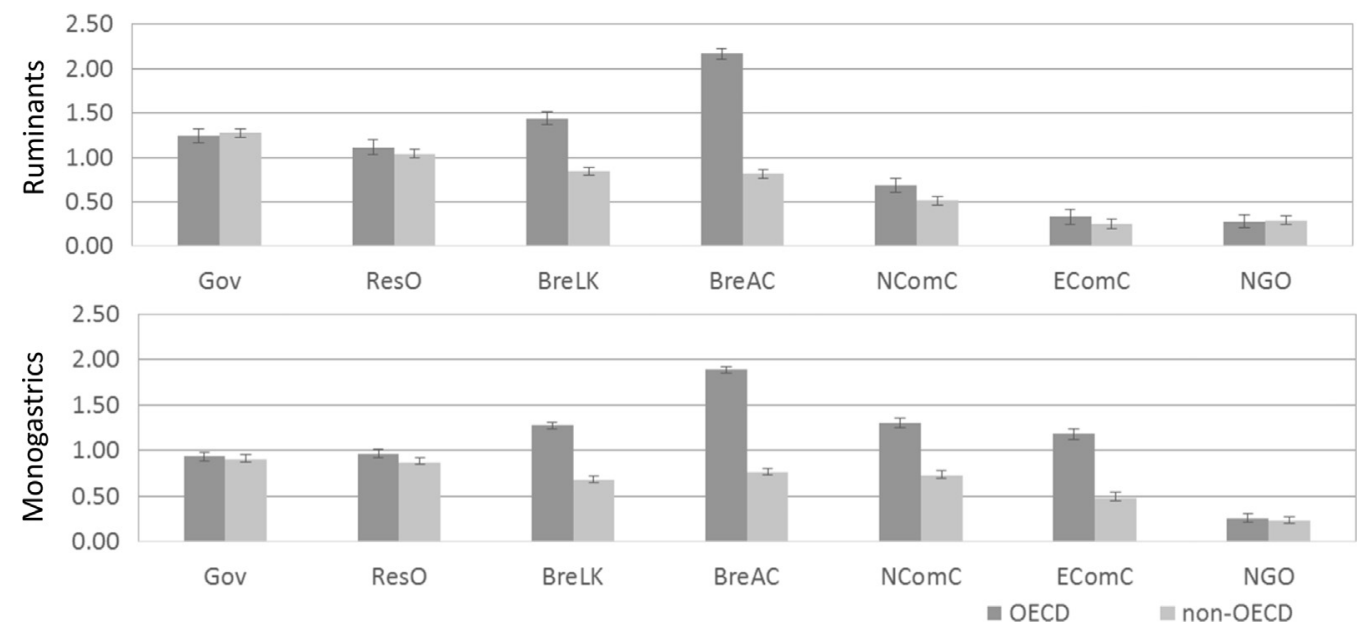

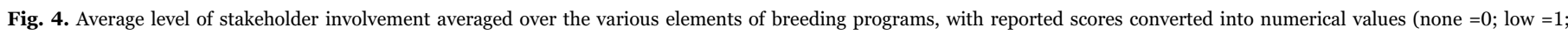

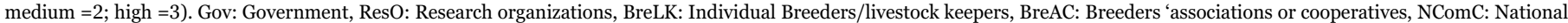
commercial companies, EComC: External commercial companies, NGO: Non-Governmental organizations.

'associations or cooperatives).

3.2.3. Methods used for in situ conservation programs by the private and public sector

When considering involvement of the private and public sector in conservation activities (Fig. 6), a larger proportion of OECD countries reported involvement of both sectors in different kinds of activities, with the exception of those related to community-level participation and empowerment. Involvement of public and private sectors differed between countries and depended on breeding activities, For instance, in OECD countries, private sector involvement was more frequently reported for promotion activities (niche marketing, touristic attraction and breed-related cultural activities), while for both OECD and nonOECD countries, involvement of the public sector was more frequently reported in relation to incentives for keeping at-risk breeds and extension services.

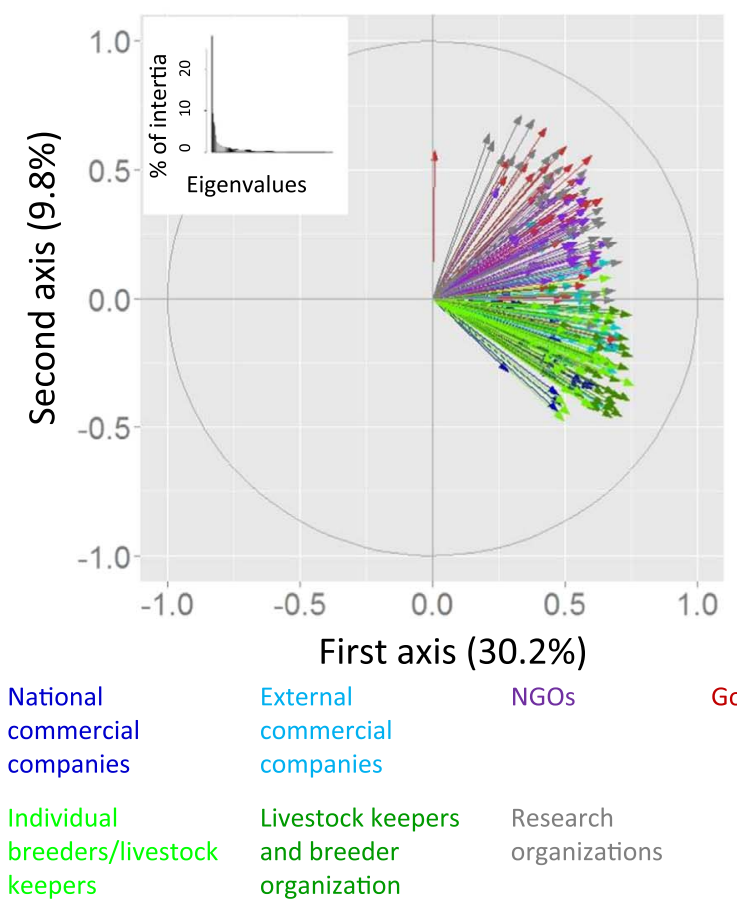

Correlation circle of variables
Despite these differences across activities (Fig. 7), PCA results differentiated countries through (i) the general degree of involvement (average correlation across variable 33\%, and first axis accounting for $36.5 \%$ of intertia), and (ii) involvement of the private versus public sector. Many OECD countries reported relative large involvement by both sectors, but the importance of the private versus public sector differed substantially among OECD countries, with some countries relying largely on the private sector (USA, Netherlands NLD), while other relied more on the public sector (Portugal PRT). Countries that were most reliant on the public sector for those activities were essentially all non-OECD countries (e.g., Bhutan BTN, Vietnam VNM, Algeria DZA,).

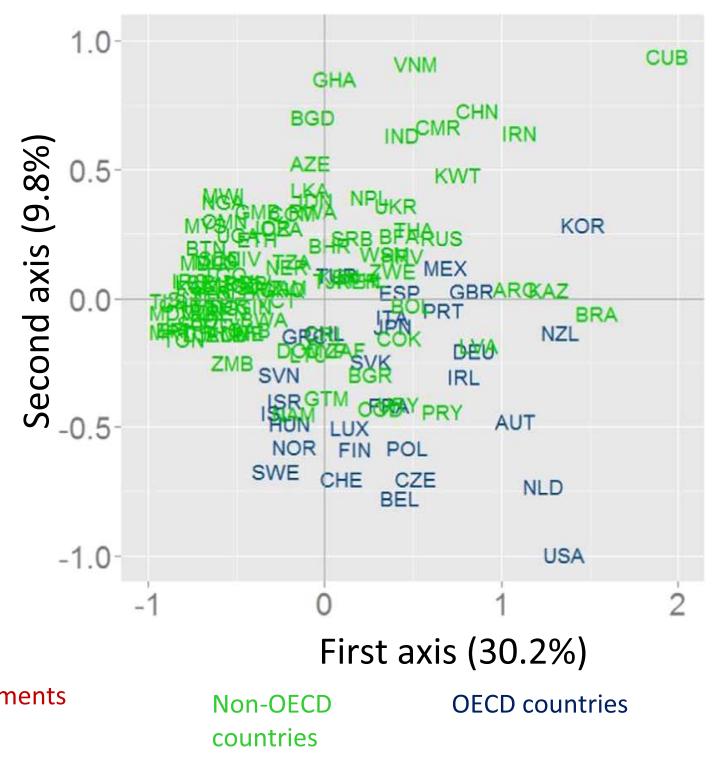

Plotting of countries

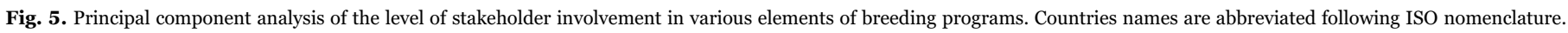


Table 2

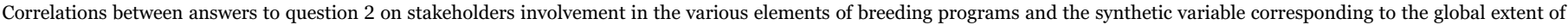
AnGR activities (computed in Leroy et al., 2016b).

\begin{tabular}{|c|c|c|c|c|c|c|c|c|}
\hline Country set & Governments & $\begin{array}{l}\text { Research } \\
\text { organizations }\end{array}$ & $\begin{array}{l}\text { Individual } \\
\text { Breeders/ } \\
\text { livestock } \\
\text { keepers }\end{array}$ & $\begin{array}{l}\text { Breeders 'associations } \\
\text { or cooperatives }\end{array}$ & $\begin{array}{l}\text { National } \\
\text { commercial } \\
\text { companies }\end{array}$ & $\begin{array}{l}\text { External } \\
\text { commercial } \\
\text { companies }\end{array}$ & $\begin{array}{l}\text { Non-Governmental } \\
\text { organizations }\end{array}$ & Average \\
\hline $\begin{array}{l}30 \text { OECD } \\
\text { countries }\end{array}$ & $\begin{array}{l}0.05 \\
(0.05)\end{array}$ & $\begin{array}{l}0.09 \\
(0.06)\end{array}$ & $\begin{array}{l}0.13 \\
(0.04)\end{array}$ & $\begin{array}{l}0.41 \\
(0.06)\end{array}$ & $\begin{array}{l}0.2 \\
(0.06)\end{array}$ & $\begin{array}{l}0.23 \\
(0.06)\end{array}$ & $\begin{array}{l}0.14 \\
(0.04)\end{array}$ & $\begin{array}{l}0.18 \\
(0.06)\end{array}$ \\
\hline $\begin{array}{l}98 \text { non-OECD } \\
\text { countries }\end{array}$ & $\begin{array}{l}0.48 \\
(0.03)\end{array}$ & $\begin{array}{l}0.53 \\
(0.04)\end{array}$ & $\begin{array}{l}0.42 \\
(0.02)\end{array}$ & $\begin{array}{l}0.59 \\
(0.02)\end{array}$ & $\begin{array}{l}0.4 \\
(0.04)\end{array}$ & $\begin{array}{l}0.18 \\
(0.03)\end{array}$ & $\begin{array}{l}0.36 \\
(0.04)\end{array}$ & $\begin{array}{l}0.42 \\
(0.05)\end{array}$ \\
\hline $\begin{array}{l}\text { Total } 128 \\
\text { countries }\end{array}$ & $\begin{array}{l}0.28 \\
(0.06)\end{array}$ & $\begin{array}{l}0.34 \\
(0.07)\end{array}$ & $\begin{array}{l}0.44 \\
(0.03)\end{array}$ & $\begin{array}{l}0.68 \\
(0.03)\end{array}$ & $\begin{array}{l}0.34 \\
(0.06)\end{array}$ & $\begin{array}{l}0.24 \\
(0.06)\end{array}$ & $\begin{array}{l}0.24 \\
(0.03)\end{array}$ & $\begin{array}{l}0.37 \\
(0.07)\end{array}$ \\
\hline
\end{tabular}

Correlations were averaged by stakeholder. Standard errors are shown in brackets.

\section{Discussion}

\subsection{Factors impacting stakeholder involvement}

The analysis allowed identification of factors explaining the extent of stakeholders involvement in AnGR management activities. The country reports clearly demonstrated differences in involvement among animal species, activities, and countries. The question regarding stakeholder involvement in elements of breeding programs showed that breeders/livestock keepers (either individually, or organized in associations or cooperatives), governments, and research organization were major stakeholders, in comparison to commercial companies and NGOs (Fig. 4). The greater reported involvement of commercial companies in monogastric species is related to both logistic and economic considerations, as some biological parameters in these species (medium to small animal size, high prolificacy, low generation intervals, ability to merchandize hybrid offspring) allow (i) small numbers of industrial operators to manage integrated breeding schemes, and (ii) vertically integrated market chains that include breeding services (see Narrod and Fuglie, 2000). Stakeholder involvement also differs among breeding activities, with, for example, research organizations more involved in setting breeding goals and the conduct of genetic evaluations and less involved in services such as recording, animal identification or provision of artificial insemination services. Some activities related to conservation programs, such as providing incentives for keeping breeds at risk, are carried out almost exclusively by the public sector. Most of all, the involvement of stakeholders differs among countries, with developed/OECD countries generally reporting greater involvement of stakeholders, but also relying more on breeders/livestock keepers (individually and collectively) and commercial companies compared to governments and research organizations to implement breeding programs (Fig. 5). However, PCA results also demonstrated that the involvement of different stakeholders may vary widely among both developed and developing countries (Figs. 5 and 7). As discussed previously, the involvement of stakeholders is highly dependent on the nation's political and historical background which, at a minimum, impacts the involvement of the state in agricultural and livestock breeding activities. Various factors may also interact; for instance, differences in the involvement of government and research organizations were limited between OECD and non-OECD countries, but differences were much more important when considering the involvement of breeders/livestock keepers and commercial companies

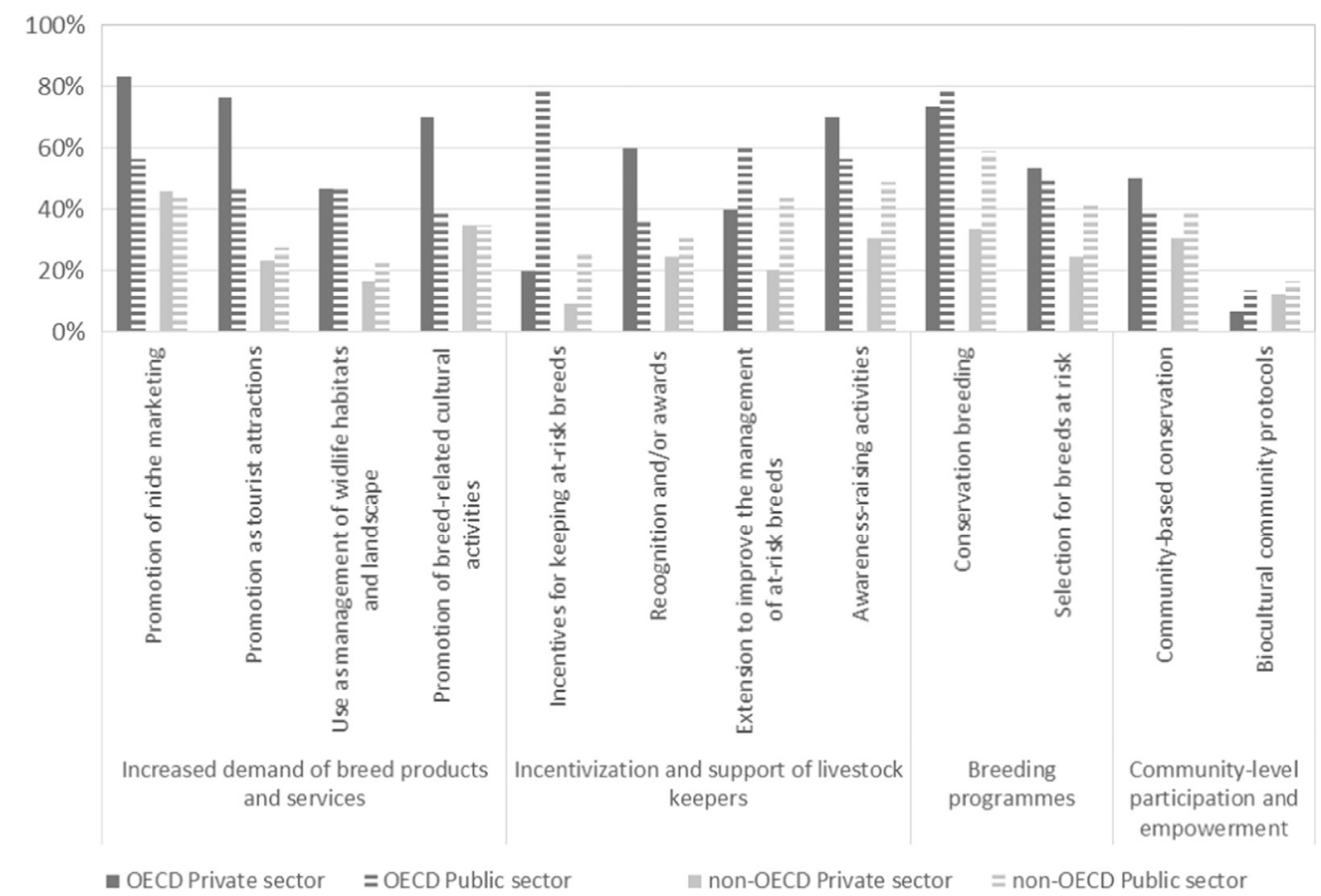

Fig. 6. Proportion of countries reporting involvement of the private and public sector in activities related to in situ conservation programs. 


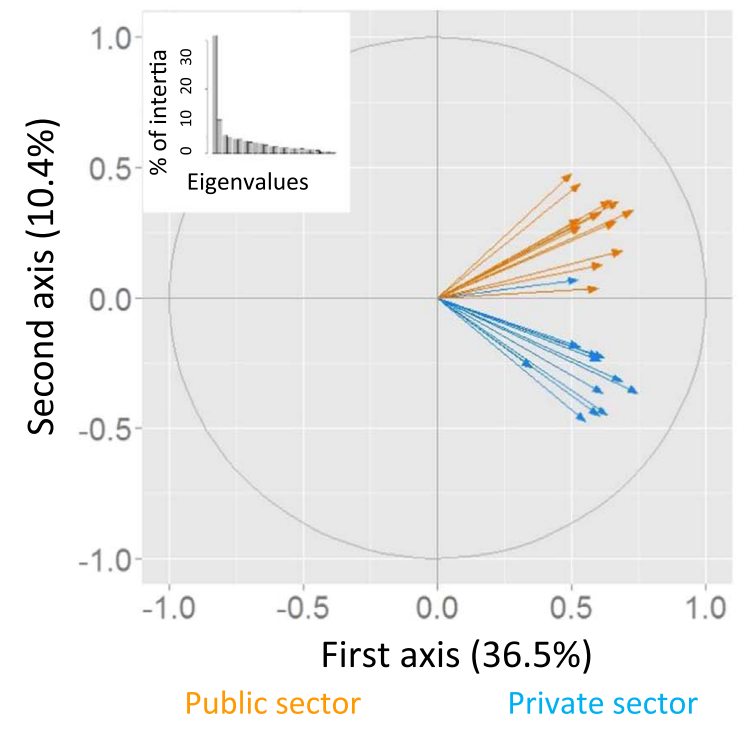

\section{Correlation circle of variables}

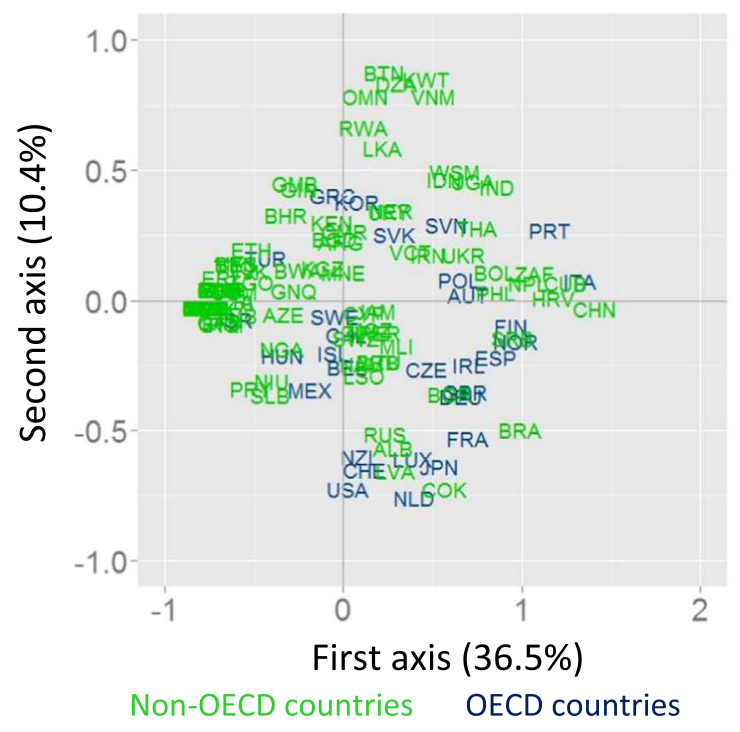

Plotting of countries

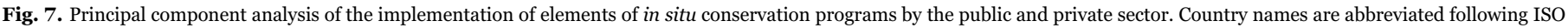
nomenclature.

(Fig. 4). Low (although not nonexistent) involvement of commercial companies relative to other stakeholders in the management of AnGR in southern and eastern African was illustrated by Zonabend et al. (2013).

From an analytical perspective, it would have been interesting to compare the current situation in OECD countries with the conditions present in these countries at earlier stages of development (e.g., when the percentages of the population employed in agriculture was comparable to that in the current set of non-OECD counties) to determine if both sets of countries appear to be moving forward on a common development path. The context is of course different, but our historical review suggested that the improvement of AnGR management capacities in the developed countries was associated with substantial support from national policies and dedicated public institutions.

The analysis of the country reports provided interesting results on the involvement of stakeholders. Our analysis was based on country reports, which necessarily reflected the judgement of national coordinators and advisory committees. It is also possible that some questions were interpreted in slightly different ways. The country reports also do not provide information on current tendencies in term of stakeholder involvement. However, a report on livestock production in Asia provided interesting information on the recent evolution of stakeholder involvement (Anon, 2013). This report confirmed, for instance, the dominance of the government husbandry department in provision of service such as AI in India, but also documented that an increasing number of AI centres were run by cooperatives, NGOs and the private sector. In China, the report indicated a gradual replacement of small pig producers by industrial ones.

\subsection{Stakeholders involvement and extent of AnGR activities}

The extent of AnGR-related activities, including both breeding activities (e.g., setting breeding goals, genetic evaluation, artificial insemination, cryoconservation, etc.) and the livestock populations covered (number of breeds and individuals) should intuitively be expected to increase with greater stakeholder involvement, but the relationship is actually complex, as illustrated in Table 2. Based on country reports, the overall correlation between stakeholder involvement and extent of AnGR activities was positive. However, when considering OECD countries, the correlation was weak, especially when considering involvement of government and research organizations in breeding programs. This result does not mean that involvement of public actors is not required for AnGR management as such, as they are major stakeholders for various characterization and conservation activities, even in developed countries (Fig. 6). However, the analysis of the country reports and our historical perspective emphasized that public support is required in the early steps of capacity development. Also, as illustrated in Fig. 6, some activities, especially relative to AnGR conservation, rely mainly on public services such as incentives and extension assistance to keep at-risk breeds and improve their management. In both OECD and non-OECD countries, the highest correlation between the extent of AnGR activities and stakeholder involvement was found for breeders' associations or cooperatives, illustrating the importance of those stakeholders and in agreement with results of Rewe et al. (2009). The results emphasize that the success of breeding activities depends largely on the participation and coordination of stakeholders (Amati and Parkins, 2011).

In developing countries, government-managed centralized breeding schemes to improve local breeds have commonly been carried out on research stations with limited farmers participation and often have not been successful (Wurzinger et al., 2011). In a review of small-ruminant breeding programs by Kosgey et al. (2006), the main factors associated with the success of breeding programs were (i) compatibility with the breeding objective of the farming system and the involvement of smallholders, with greater organization of the farmers simplifying the implementation of breeding schemes, and (ii) the existence of market incentives and support services. Also, as underlined by Herold et al. (2012), potential conflicts between private and public interests also must be addressed when implementing breeding policies. In developing countries, policies and related investments in AnGR development should therefore emphasize community development, the integration of stakeholders, and the involvement of smallholders. The latter may require specific technologies and training adapted to smallholders, in contrast to the more traditional public sector knowledge and technology transfer (Tarawali et al., 2011). Different examples of communitybased approaches have shown that external support from various stakeholders is needed to ensure long-term sustainability (Mueller et al., 2015). Therefore, the commitment of all involved institutions, and not just individuals, is required. A charismatic person (champion) can be an inspiring and convincing leader and can stimulate others to 
join the effort, but programs such as these can come to a sudden end if the person does not continue.

\subsection{Prospective around evolution of involvement of stakeholders}

As illustrated above, involvement of actors is a dynamic process, with, for instance, a clear tendency towards greater involvement of private companies in developed and emerging countries (Anon, 2013; Duteurtre et al., 2015). Development of new technologies is likely to impact the governance of breeding activities, and alter the balance between stakeholders. Labatut (2015) analysed for instance how genomic selection led to major organizational change in French dairy cattle breeding, with increased competition between actors that previously cooperated as partners, and with the planning of matings increasingly transferred from farmers to breeding companies. Increasing involvement of private companies can therefore raise concerns about the management of breeds and breeding decisions. Emerging technologies such as genome editing may also change the view of AnGR as a common good. Changes such as these will, at the least, require the definition of new relationships and new rules of coordination.

\section{Conclusions}

One of the aims of our study was to investigate how involvement of stakeholders in AnGR management varied among activities and countries. Among other factors, it appeared that the involvement of a given stakeholder group was highly dependent on the historical background and ideas guiding development policies and donor involvement. This finding is in agreement with Coleman (1998). In terms of relationships between stakeholder involvement and development of AnGR activities, our results suggest that promoting coordination among breeders/livestock keepers through creation and empowerment of cooperatives, associations, or community-based approaches should be a priority for policy-makers and donors, and that coordination between the different stakeholders should be encouraged. The environmental, economic and technological context in relation to AnGR is likely to evolve rapidly over the next few years, and may drastically alter existing relationships among actors. As discussed by Labatut (2015), it is therefore especially important to define evolving rules and opportunities of coordination among stakeholders.

\section{Conflict of interest statement}

We wish to confirm that there are no known conflicts of interest associated with this publication and there has been no significant financial support for this work that could have influenced its outcome. We confirm that the manuscript has been read and approved by all named authors and that there are no other persons who satisfied the criteria for authorship but are not listed. We further confirm that the order of authors listed in the manuscript has been approved by all of us.

\section{Disclaimer}

The views expressed in this information product are those of the authors and do not necessarily reflect the views or policies of FAO.

\section{Acknowledgements}

The authors would like to thank the French Government for providing for the secondment of Dr Gregoire Leroy to FAO, countries for information provided, and reviewers for their useful comments.

\section{References}

Amati, C., Parkins, J.R., 2011. Improved Goat Breeding and Mixed Crop Farming in East Africa: A literature review. ILRI, Nairobi, Kenya.

Anon, Ahuja, V., Vin. (Eds), 2013. Asian Livestock: Challenges, opportunities and the response. In: Proceedings of an International Policy Forum held in Bangkok, Thailand, 16-17 August 2012, Animal Production and Health Commission for Asia and the Pacific, ILRI and FAO, Bangkok.

Bougler, J., Delage, J., 1999. Des herdbooks aux UPRA. Ethnozootechnie 63, 69-78.

Byerlee, D., Echeverría, R.G. (Eds.), 2002. Agricultural research policy in an era of privatization. CABI, Wallingford Oxon.

Carvalheiro, R., 2014. Genomic Selection in Nelore Cattle in Brazil. In: 10th World Congress on Genetics Applied to Livestock Production, Vancouver.

Coleman, W.D., 1998. From protected development to market liberalism: paradigm change in agriculture. J. Eur. Public Policy 5, 632-651.

Conelly, W.T., 1998. Colonial era livestock development policy: introduction of improved dairy cattle in high-potential farming areas of Kenya. World Dev. 26, 1733-1748.

Duteurtre, G., Cesaro, J.D., Nguyen Mai, H., Pham Duy, K., Nguyen Ngoc, L., 2015. The TH dairy company (Vietnam): Is such a large-scale investment sustainable?, Report of a visit conducted in Nghĩa Đàn District (Nghệ An Province) on July In: Proceedings of the 2nd, 2015 completed with a literature review, Revalter Working paper, Cirad, Hanoi,

Faco, O., Lobo, R.N.B., Gouveia, A.M.G., Guimaraes, M., Fonseca, J.F., dos Santos, T.N.M., da Silva, M.A.A., Villela, L.C.V., 2011. Breeding plan for commercial dairy goat production systems in southern Brazil. Small Rumin. Res. 98, 164-169.

FAO, 2015. The Second Report on the State of the World's Animal Genetic Resources forFood and Agriculture, Scherf, B.D., Pilling, D., (Eds), FAO Commission on Genetic Resources for Foodand Agriculture Assessments, Rome.

Ferraz, J.B.S., Eler, J.P., 2010. Parceria público x privada no desenvolvimento de pesquisa em melhoramento genético animal. Rev. Bras. Zootecn 39, 216-222.

Friedmann, H., McMichael, P., 1989. Agriculture and the state system: the rise and decline of national agricultures, 1870 to the present. Sociol. Rural. 29, 93-117.

Havenstein, G.B., Ferket, P.R., Qureshi, M.A., 2003. Carcass composition and yield of 1957 versus 2001 broilers when fed representative 1957 and 2001 broiler diets. Poult. Sci. 82, 1509-1518.

Herold, P., Rößler, R., Momm, H., Valle Zárate, A., 2012. Development of organisation and planning in animal breeding: II. A review on breeding planning. Arch. Tierz. 55, 519-531.

Hove, G., 2015. The State, Farmers and Dairy Farming in Colonial Zimbabwe (Southern Rhodesia), c. 1890-1951, Stellenbosch University, Stellenbosch.

Josse, J., Husson, F., 2012. Handling missing values in exploratory multivariate data analysis methods. J. De. la SFdS. 153, 79-99.

Kosgey, I.S., Baker, R.L., Udo, H.M.J., Van Arendonk, J.A.M., 2006. Successes and failures of small ruminant breeding programs in the tropics: a review. Small Rumin. Res. 61, 13-28.

Labatut, J., 2015. Opinion paper: emerging markets, emerging strategies under the genomic revolution. Animal 9, 735-737.

Labatut, J., Aggeri, F., Allaire, G., 2013. Etudier les biens communs par les changements institutionnels: regimes de propriété autour des races animales face à l'innovation génomique. Rev. Regul. 14〈http://regulation.revues.org/10529〉.

Lauvie, A., Audiot, A., Couix, N., Casabianca, F., Verrier, E., 2011. Diversity of rare breed management programs: between conservation and development. Livest. Sci. 140, $161-170$.

Leroy, G., Baumung, R., Boettcher, P., Scherf, B., Hoffmann, I., 2016a. Review: sustainability of crossbreeding in developing countries; definitely not like crossing a meadow. Animal 10, 262-273.

Leroy, G., Besbes, B., Boettcher, P., Hoffmann, I., Pilling, D., Baumung, R., Scherf, B., 2016b. Factors and determinants of animal genetic resources management activities across the world. Livest. Sci. 189, 70-77.

Mueller, J., Rischkowsky, B., Haile, A., Philipsson, J., Mwai, O., Besbes, B., Valle Zárate, A., Tibbo, M., Mirkena, T., Duguma, G., 2015. Community based livestock breeding programs: essentials and examples. J. Anim. Breed. Genet. 132, 155-168.

Narrod, C.A., Fuglie, K.O., 2000. Private investment in livestock breeding with implications for public research policy. Agribusiness 16, 457-470.

National Research Council, 1995. Colleges of Agriculture at the Land Grant Universities: A Profile. The National Academies Press, Washington DC.

OECD, 2015. OECD countries: Producer support estimate by country. 〈http://stats.oecd. org/Index.aspx?DataSetCode=MON20123_5〉 (accessed 13.01.16).

Ogbimi, F.E., Oyewale, A.A., 2000. Analysis of the experience of developing the dairy industry in Southwestern Nigeria. Food Rev. Int. 16, 485-502.

Rewe, T.O., Herold, P., Kahi, A.K., Valle Zárate, A., 2009. Breeding indigenous cattle genetic resources for beef production in Sub-Saharan Africa. Outlook Agr. 38, 317-326.

Stads, G.J., Beintema, N.M., 2009. Public agricultural research in Latin America and the Caribbean: Investment and capacity trends, Agricultural Science and Technology Indicators (ASTI) Synthesis Report, Washington.

Tarawali, S., Herrero, M., Descheemaeker, K., Grings, E., Blümmel, M., 2011. Pathways for sustainable development of mixed crop livestock systems: Taking a livestock and pro-poor approach. Livest. Sci. 139, 11-21.

Vissac, B., 2002. Les vaches de la République. INRA Editions, Paris.

Wood, R.J., Orel, V., 2001. Genetic Prehistory in Selective Breeding: A Prelude to Mendel. Oxford University Press, New York.

Wurzinger, M., Solkner, J., Iniguez, L., 2011. Important aspects and limitations in considering community-based breeding programs for low-input smallholder livestock systems. Small Rumin. Res. 98, 170-175.

Zonabend, E., Okeyo, A.M., Ojango, J.M.K., Hoffmann, I., Moyo, S., Philipsson, J., 2013. Infrastructure for sustainable use of animal genetic resources in Southern and Eastern Africa. Anim. Genet. Res. 53, 79-93. 